\title{
ANÁLISE DO DISCURSO JORNALÍSTICO SOBRE A MULHER NA POLÍTICA
}

\author{
AUTOR: CARLOS ALBERTO MARQUES DE OLIVEIRA \\ CO-AUTOR/ORIENTADOR: FERNANDA LUZIA LUNKES
}

Resumo: Vinculado ao projeto "O discurso sobre gênero na mídia: efeitos de produções de evidências e processos de silenciamentos", este trabalho objetiva apresentar questões e resultados da pesquisa desenvolvida na modalidade de iniciação científica (2019/2020), com auxílio da Fapesb. A partir dos dispositivos teórico-analíticos da Análise materialista de Discurso (PÊCHEUX, 1997), a pesquisa analisou os processos de produção de sentido(s) sobre a mulher na mídia em posições de poder. Com base em Dela Silva (2012), concebe-se mídia enquanto lugar que detém o privilégio de constituir e fazer circular determinados efeitos de sentidos. Para os procedimentos de análise, elegemos como objetos capas das revistas semanais Época, IstoÉ nas quais Dilma Rousseff comparece, fazendo um recorte temporal de 2015 e 2016, período que coloca em questão algumas das tensões sociais e políticas daquela conjuntura: as primeiras manifestações em torno do pedido de impeachment até a abertura e consolidação do processo. Um amplo levantamento foi feito nas edições publicadas no período selecionado e deste algumas capas foram selecionadas para compor o corpus discursivo. Foram feitos recortes de elementos verbais e não-verbais sobre a então ex-presidenta Dilma Rousseff, com foco para o funcionamento da memória e os processos de silenciamentos que constituem os gestos de interpretação da mídia sobre a mulher no poder. As análises permitiram depreender a mobilização de gestos de violência (LUNKES, 2018) em dizeres e imagens sobre Dilma Rousseff, especialmente a partir da sobreposição de "lugares discursivos" (GRIGOLETTO, 2007) entre mulher e presidenta. Tais gestos produzem um forte efeito de negativização da posição de presidenta, produzindo evidências em torno da necessidade de desligamento do cargo a partir de efeitos de despreparo, histeria e desequilíbrio emocional. No decorrer da pesquisa, a página "Mulheres em luta" foi criada na rede social Facebook, cujos conteúdos compartilhados relacionam-se sobretudo à violência contra a mulher. Como criação exclusiva da pesquisa, produziu-se um material audiovisual que traz, enquanto prática de escuta, entrevistas realizadas com a professora Dantielli Garcia e a artista Letrux (Letícia Novaes). Nessas entrevistas, ambas apresentam suas tomadas de posição sobre o processo do golpe/impeachment e a imagem construída pela mulher no discurso midiático.

Palavras-chave: Análise de Discurso, Mídia, Mulher, Política, Gestos de violência. 